\title{
Changes in temperature tolerance of Balanus balanoides during its life-cycle
}

\author{
Dennis J. Crisp and David A. Ritz \\ Marine Science Laboratories, Menai Bridge, Anglesey, N. Wales, U.K.
}

KURZFASSUNG: Veränderungen der Temperaturtoleranz von Balanus balanoides während seines Lebenszyklus. In Nordwales weisen die oberen Letaltemperaturen des Cirripediers $B$. balanoides nur geringe jahreszeitliche Variationen auf. Jedoch treten je nach der Jahreszeit merkbare Resistenzveränderungen bei Temperaturen unter Null auf, wobei die untere Letaltemperatur von $-6,0^{\circ} \mathrm{C}$ im Juni bis zu $-17,6^{\circ} \mathrm{C}$ im Januar schwankt. Eine außergewöhnlich starke Kältetoleranz wird in der Zeit von Dezember und Januar erworben und zwischen Februar und April wieder verloren. Obwohl diese Zeitspanne mit der Oviposition beziehungsweise dem Schlüpfen der Nauplien zusammenfallen, konnte festgestellt werden, daß die Kältetoleranz nicht notwendigerweise vom Brutzyklus abhing oder diesen begleitete. Unter Laboratoriumsbedingungen wurde von kalt gehaltenen Tieren eine Kälteresistenz nicht erworben, auch ging diese bei Tieren, die während des Frühlings im Labor verblieben, nicht verloren. Es ließ sich nicht beweisen, daß Veränderungen in der Ernährung oder Anderungen in der Tageslänge zu einem Verlust der Kälteresistenz führen. Die Cypriden waren wesentlich weniger widerstandsfähig, sowohl gegenüber hohen wie niedrigen Temperaturen, als überwinternde Adulte und die ältesten Embryostadien. Während der Metamorphose zeigte sich eine merkliche Erhöhung der Temperaturresistenz. Das Auftreten der Kälteresistenz beim Adultus fiel mit einer Periode "physiologischen Winterschlafs" zusammen, wobei gewisse Gewebe reduziert wurden und Nahrungsaufnahme, Atmung und biosynthetische Aktivität nachließen. Dieser stoffwechselphysiologische Aktivitätsrückgang könnte ein Faktor sein, der die beobachtete erhöhte Kältetoleranz fördert. Außerdem wird möglicherweise auch die Zusammensetzung der Körperflüssigkeiten während des Winters so verändert, daß die Gewebe geschützt werden.

\section{INTRODUCTION}

In spite of the voluminous literature on temperature tolerance and adaptation, no single animal has been subjected to a complete study of resistance to high and low temperature throughout its life cycle from egg to adult, and during the seasons.

The boreo-arctic barnacle Balanus balanoides has many advantages for such a study. It is abundant, and, being sessile, the past environmental history of selected specimens is known. Since it must withstand extremely low temperatures in winter at its northern limits in the high arctic (PETERSEN 1962) and high temperatures when as an adult it is exposed to the sun in the summer, it must possess an exceptionally wide range of temperature tolerance. It is convenient to work with on account of its ability to survive starvation and desiccation for long periods. Moreover, the annual breeding 
cycle (MOORE 1935) implies that the individuals collected at a given time are in a similar physiological state.

\section{METHODS FOR MEASURING LETHAL LIMITS}

The median lethal temperature (M.L.T.) of a population in a given physiological state may vary considerably with the method of measurement. The relative merits of different methods have been assessed by Fry (1957), Dickie \& Medcof (1963), SouthWard (1958), and Hoff \& Westman (1966). Some investigators, HunTSMan \& Sparks (1924), Evans (1948), and Southward (1958), have employed the method of gradually raising the animals' temperature and withdrawing samples at intervals to estimate survival rates. Others, Hathaway (1927), Doudoroff (1942), Orr (1955), and $F_{R Y}$ (1947), have transferred the animals to a constant temperature bath, thereby raising the temperature as rapidly as possible, consistent with the animals' thermal capacity and conductivity, and measured the mortality - time relationship. Whichever method is used, it is necessary to define the time scale in order to select a characteristic value for the median lethal temperature. By the first method the rate of heating must be defined, since the animals display higher M.L.T.'s as the rate of rise in temperature increases (BOVEe 1949); by the second method the time of stay at elevated temperature must be defined, because the animals will display higher M.L.T.'s the shorter the time that they are heated. FRY (1957) favours the second method using very long experimental periods, because the lethal temperatures so obtained are likely to be more closely applicable to thermal requirements in the natural state. He criticizes the first method because he regards the results as "difficult to interpret", presumably because of its irrelevance to natural conditions. However, provided that rates of rise in temperature are stated and provided they are regarded only as a comparative index of tolerance, the first method appears to us valid and has the advantage of rapidity and convenience. For these reasons it had been employed previously by SouTHWARD (1958) on the species with which we intended to work, and we therefore considered it undesirable to adopt a different technique.

The corresponding method was not possible for the measurement of low temperature tolerance, since a uniform temperature and rate of cooling could not be achieved in a frozen system. We therefore had to adopt the more laborious method of measuring mortality after a given time at a series of constant temperatures.

\section{SEASONAL CHANGES IN TOLERANCE}

FRY (1957) draws attention to the influence on the upper limit of tolerance of the environmental temperature at which the animals have been kept, illustrating this by means of the tolerance trapezoid. As can be seen from Table 1, the upper lethal limits have been shown to vary with the seasons in a variety of arthropods and other animals, being higher in summer than in winter. Paradoxical resistance adaptation 
Table 1

Records of seasonal increases in tolerance to high temperature in invertebrates

\begin{tabular}{|c|c|c|}
\hline Animal & $\begin{array}{l}\text { Change in lethal } \\
\text { temperature }\end{array}$ & Reference \\
\hline Various marine invertebrates & $0.6-1.3 \mathrm{deg} C$ & VERNON 1899 \\
\hline Calanus finmarchicus & $24^{0}-26^{0} \mathrm{C}$ & Marshall, Nicholls \& OrR 1935 \\
\hline Gammarus limnaeus & $26^{0}-32^{\circ} \mathrm{C}$ & KROG 1954 \\
\hline $\begin{array}{l}\text { Orconectes propinquus } \\
\text { Cambarus fodiens }\end{array}$ & $\begin{array}{l}\text { Increased tolerance } \\
\text { of } 34^{0}-35^{\circ} \mathrm{C}\end{array}$ & BOVBJERg 1952 \\
\hline Emerita talpoida & $10 \mathrm{deg} C$ & EDWARDS \& IRVING 1943 \\
\hline $\begin{array}{l}\text { Hemigrapsus nudus } \\
\text { Hemigrapsus oregonensis }\end{array}$ & $\begin{array}{l}0.7 \operatorname{deg} C \\
0.7 \operatorname{deg} C\end{array}$ & Todo \& Dehnel 1960 \\
\hline Hydropsyche angustipennis & $31^{0}-32^{\circ} \mathrm{C}$ & MarLIer 1949 \\
\hline Messor semirufus & $40.2^{0}-43.1^{0} \mathrm{C}$ & BODENHEIMER \& KLEIN 1930 \\
\hline
\end{tabular}

(Precht 1964) may also occur in which winter animals can sustain temperatures higher than those tolerated by animals during summer, but is exceptional (e. g. Dickre 1958).

\section{CHANGES IN TOLERANCE WITH AGE}

ANDREws (1925) from a survey on a wide variety of marine animals concluded that young individuals, though less resistant to high temperatures, have greater powers of acclimation. Unfortunately, her methods and criteria of death were not given. GUNTER (1957) presented evidence that young poikilotherms are better able to withstand cold than their elders, a view supported by field observations during the cold winter of 1962 (CRISP et al. 1963). However, the review of BĚLEHRÁdEK (1935), and the works of Bovee (1949), Sprague (1963), and Mcleese (1956), dealing with the relation between stress-resistance, size, and age, allow no clear or coherent picture to be formed. Kinne (1963) considers that the temperature range tolerated by many species is at first narrow during early development, broadens in adulthood and declines again with senility.

\section{EXPERIMENTAL METHODS}

All barnacles used in the investigation were collected from the foreshore below the Menai Suspension Bridge at various tidal levels, and the experiments conducted or started on the day of collection. Upper lethal temperatures of adult animals were measured by raising the temperature of the sea water in which they were placed at the rate of 0.2 degrees $C$ per minute and withdrawing samples at 0.5 degree intervals near the critical temperature, as described by Southward (1958). Preliminary 
experiments indicated that the rate of rise in temperature needed to be controlled between 0.15 and 0.25 degrees $C$ per minute for consistent results, but the size of the rock to which the barnacles were attached exercised no significant influence. The upper lethal temperatures of the nauplius and cypris stages were measured similarly, but a more rapid rise was possible because temperature equilibration within so small an animal could be assumed almost instantaneous (1.0 degree $\mathrm{C}$ per min.).

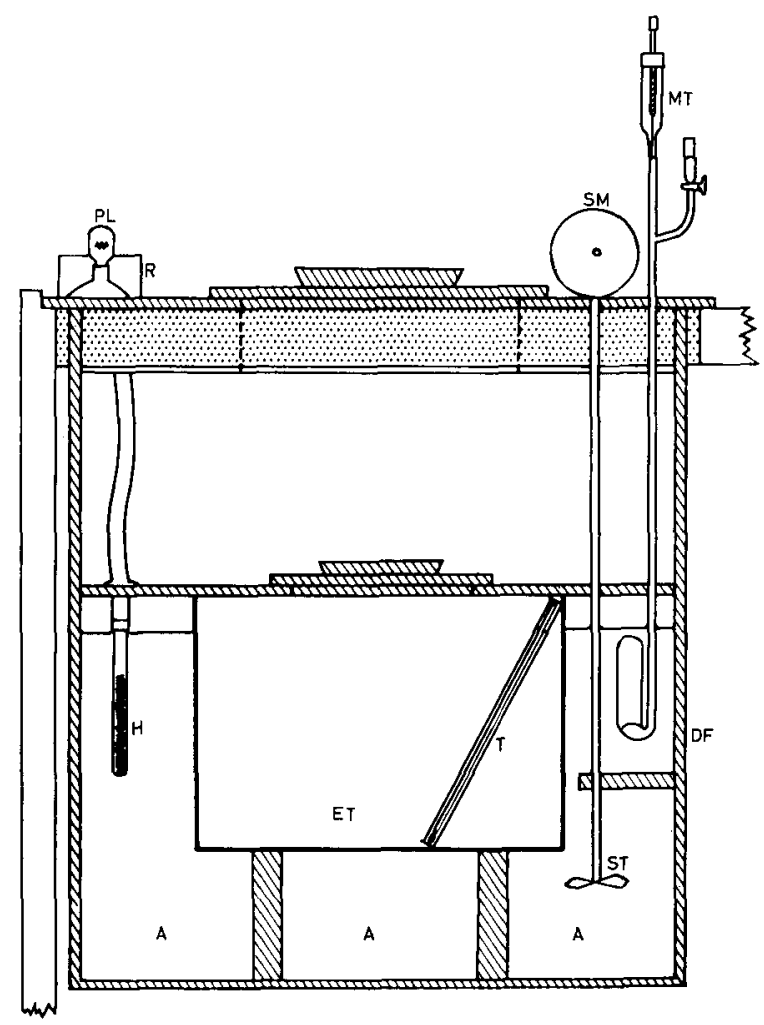

Fig. 1: Thermostatically controlled cold tank, as seen in section. A: Anti-freeze fluid, DF: interior of deep-freeze cabinet at $-25^{\circ} \mathrm{C}, \mathrm{ET}$ : experimental cold tank constructed from galvanised sheet, $\mathrm{H}$ : heater, MT: mercury toluene regulator, PL: pilot light, R: relay, SM: stirrer motor, ST: stirrer. Cross hatching: wooden components; stipple: expanded polystyrene insulator

Lower lethal temperatures were measured by placing the barnacles dry, or the larvae in sea water, in a series of low temperature jackets held constant to \pm 0.2 degrees $C$ for a period of 18 hrs. Each jacket (Fig. 1) was constructed of wood outside, metal inside, and had a heat insulating cover of expanded polystyrene; it contained ethylene glycol which was stirred continuously and held at constant temperature by a 75 watt heater operated through a toluene mercury regulator. The set of jackets operating over a series of temperatures was immersed in a deep-freeze cabinet at about 
$-25^{\circ} \mathrm{C}$. The jacket temperatures were measured by sub-zero mercury thermometers in plastic cylinders containing liquid paraffin.

Adult animals were assumed dead if after a $24 \mathrm{hr}$ recovery period in cold running sea water they failed to respond by sudden depression of the operculum to pricking with a needle. After cold treatment, one hour was also allowed for thawing out. Larvae were assumed dead if they showed no movement after exposure to high or low temperatures. A period of $48 \mathrm{hrs}$ was allowed as sometimes the larvae were very slow to recover. Developing eggs were exposed to high and low temperatures within the adults still attached to stones collected from the shore. After treatment the adults were replaced on the shore by fixing the stones to rock with rapid setting cement. The adults were removed several weeks later, and the eggs which had failed to develop further were assumed to have been killed by the treatment. Late stage egg masses containing embryos about to hatch were tested either within the adult or after removal in air and in water. Death was assumed to have occurred if successful hatching did not take place after allowing 24 hrs for recovery and applying hatching substance (CRISP 1956).

In the experiments on acclimation, barnacles were kept in glass dishes maintained either at $3.5 \pm 1^{\circ} \mathrm{C}$ or at $15.5 \pm 0.5^{\circ} \mathrm{C}$. The dishes were filled with sea water every night at the appropriate temperature, and the barnacles left dry during the day. Attempts to acclimate at $25^{\circ} \mathrm{C}$ were unsuccessful owing to heavy mortality at this temperature.

\section{RESISTANCE OF EGGS, LARVAE, AND YOUNG ADULTS TO HIGH TEMPERATURE}

The survival-temperature curves for larvae and spat are shown in Figure 2.

Adults containing eggs in mid-development in early January (Stage 9-10, CRISP 1954) were raised to a series of temperatures up to $43^{\circ} \mathrm{C}$, which was just sub-lethal to the adult, and the egg masses examined in mid February at which time they should have developed to Stage 12 but not hatched. Almost without exception the eggs had continued development indicating at least as great tolerance to raised temperature as the adult.

First and second stage nauplii tested in April after hatching gave a median lethal point of $40.0^{\circ} \mathrm{C}$ and cyprids tested in May, of $39.4^{\circ} \mathrm{C}$.

Cyprids were allowed to settle in the laboratory and were tested again immediately after metamorphosis; the M.L.T. had risen sharply to $43.6^{\circ} \mathrm{C}$, close to that of the young spat $\left(43 \cdot 8^{\circ} \mathrm{C}\right)$.

\section{SEASONAL CHANGES IN RESISTANCE OF ADULTS TO HIGH TEMPERATURE}

The M.L.T. of the adult was found to vary from $43.2^{\circ}$ to $44.0^{\circ} \mathrm{C}$ with no distinct seasonal trend (Fig. 3). Fluctuations were probably due to minor individual variations 


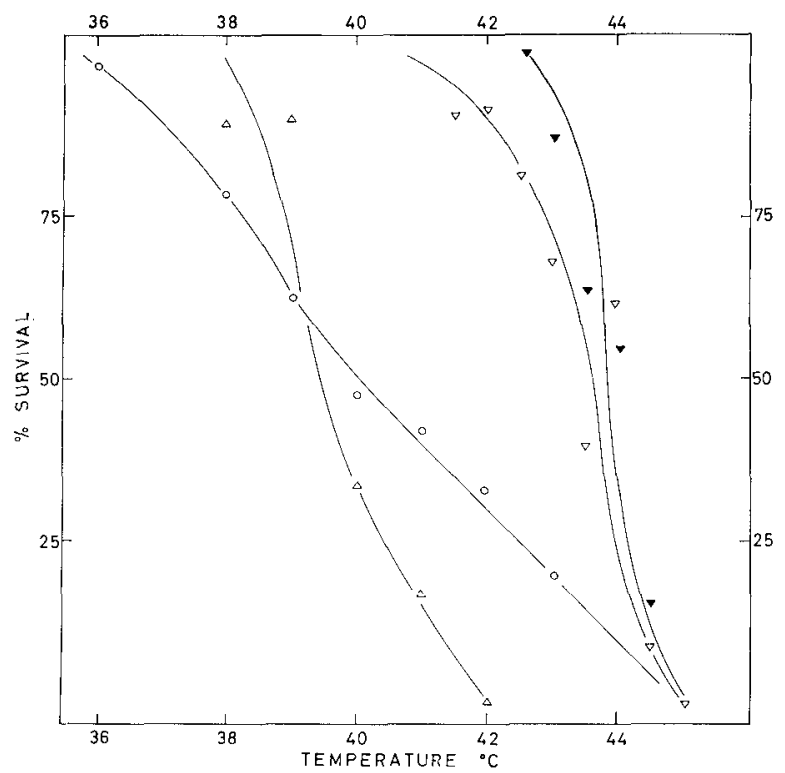

Fig. 2: Percent recovery of larvae and young spat of Balanus balanoides after exposure to high temperatures. $\bigcirc$ 1st and 2 nd stage nauplii, $\Delta$ cyprids, $\nabla$ settled unmetamorphosed cyprids, young spat

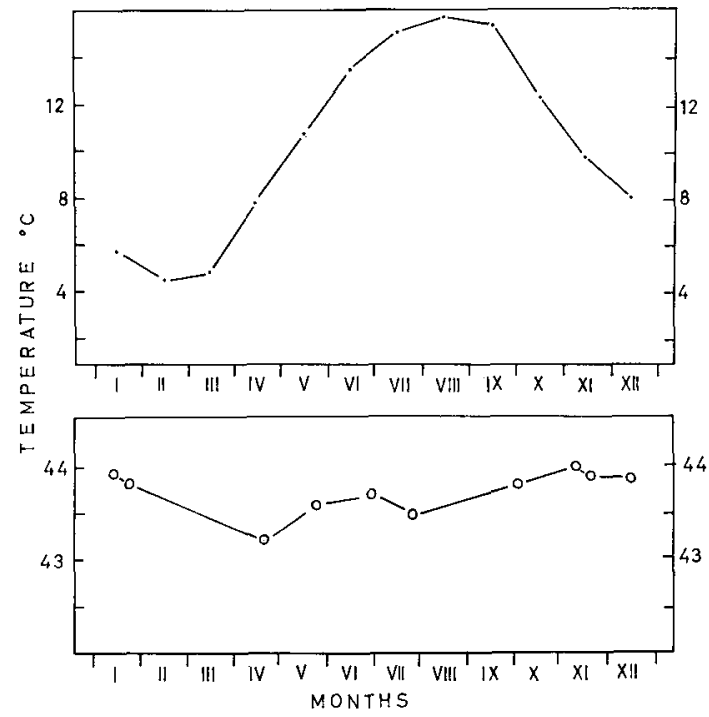

Fig. 3: Seasonal changes in heat tolerance of the adult barnacle and mean monthly sea temperatures taken at the surface at Menai Bridge Pier throughout the year. $\bigcirc$ Upper median lethal temperature of adults, -.- mean monthly sea temperatures 
within the samples. No regular difference was observed between samples taken from different shore levels.

\section{RESISTANCE OF EGGS AND LARVAE TO LOW TEMPERATURE}

The lower median lethal temperature of late stage eggs was determined under a number of conditions; with the eggs retained in the parent mantle cavity, with the egg masses removed and frozen in air, and with the egg masses removed and covered with

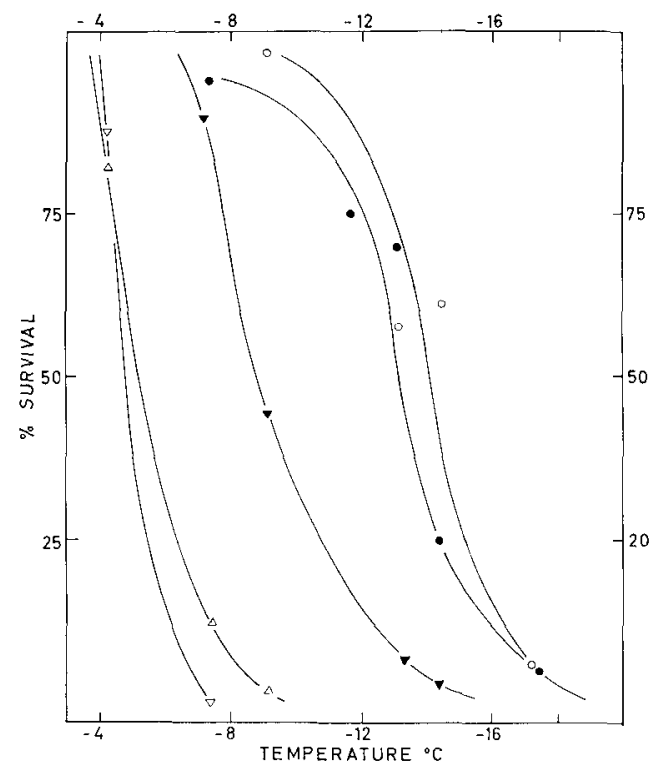

Fig. 4: Percent recovery of eggs, larvae, and young spat of $B$. balanoides after exposure to low temperatures. $\bigcirc$ Eggs (see text for description of treatment), - late stage nauplii, $\triangle$ cyprids, $\nabla$ settled unmetamorphosed cyprids, $\nabla$ young spat

a small volume of sea water. Also, some eggs were hatched with hatching substance (CRISP 1956) and the larvae frozen in water. These four methods gave essentially similar M.L.T.'s of about $-14.1^{\circ} \mathrm{C}$ and are grouped in Figure 4. This value is not precise because after freezing the larvae show different stages of debilitation rather than outright death.

The M.L.T. of the late stage nauplii $\left(-13.4^{0} \mathrm{C}\right)$ is similar to that of the eggs and first stages; evidently no appreciable change in resistance takes place as a consequence of hatching. However, the cyprids are much less tolerant than the nauplius larvae, giving values of only $-5.1^{\circ} \mathrm{C}$. A sharp change again occurs at metamorphosis; settled but unmetamorphosed cyprids still have a low resistance (M.L.T. of $-5.0^{\circ} \mathrm{C}$ ), but after metamorphosis the M.L.T. falls to $-8.8^{\circ} \mathrm{C}$. 


\section{SEASONAL CHANGES IN RESISTANCE OF ADULTS TO LOW TEMPERATURE}

The decline in cold tolerance from nauplius to cyprid coincides with a spectacular drop in resistance of the adult as can be seen from Figure 5 which illustrates the seasonal changes observed during 1964/65. Winter values of M.L.T. fell to a minimum

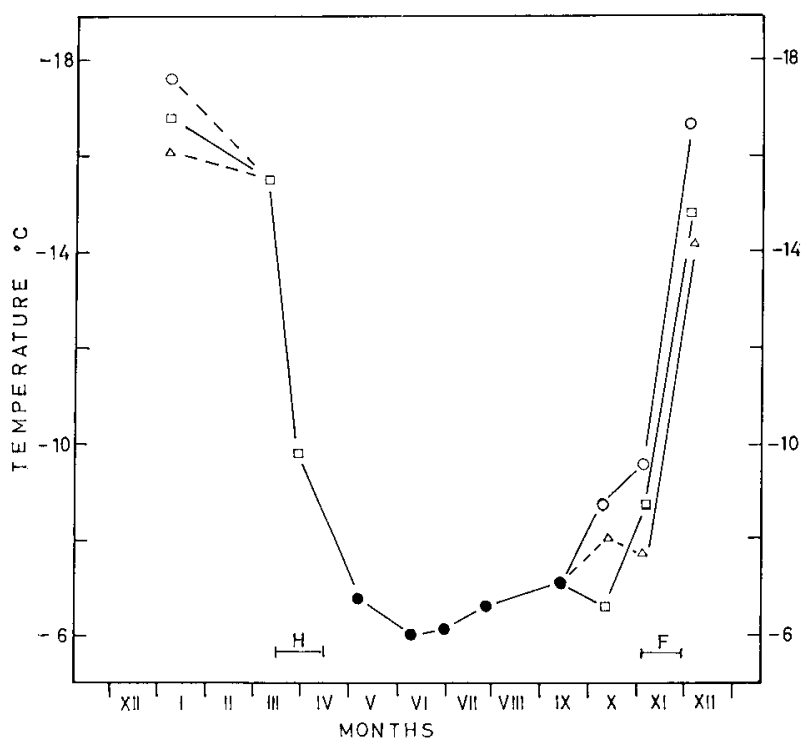

Fig. 5: Seasonal changes in cold tolerance of the adult barnacle. $\bigcirc$ Median lethal temperature (M.L.T.) of high water animals, $\square$ M.L.T. of mean tide level animals, $\triangle$ M.L.T. of low water animals, M.L.T. of combined high water and mean tide animals. F: Time of fertilization, $\mathrm{H}$ : time of hatching

of $-17.6^{\circ} \mathrm{C}$ in early January and rose gradually until March and then more rapidly to $-6.8^{\circ} \mathrm{C}$ in May. The period of least tolerance was in June, when the M.L.T. stood at $-6.0^{\circ} \mathrm{C}$. A slight decrease occurred from July to mid September, after which changes were increasingly rapid, a decrease in M.L.T. of 7 deg C taking place during November. During this period of rapid change, the animals at higher levels on the shore were more advanced in acquiring tolerance than those at lower levels.

\section{COLD TOLERANCE AND THE BREEDING CYCLE}

The rise in cold resistance begins during the period that the gonads are reaching the final stages of maturity and steepens sharply at the time when the eggs are being fertilized. Furthermore, the individuals at high shore levels are the most advanced in the acquisition of resistance to cold, just as they are the first to bear egg masses (CRISP 1955). Similarly at the end of the winter the loss of cold tolerance coincides with the 
hatching and liberation of nauplii. The question therefore poses itself, whether these changes in tolerance are dependent upon fertilisation or are linked in some precise way with the breeding cycle. We therefore investigated the relationship between cold tolerance and the presence of egg masses in the mantle space.

Figure 6 shows the mortality-temperature curves for ovigerous and nonovigerous individuals during the period when oviposition was taking place and for animals at different shore levels. Although there was a significant difference between

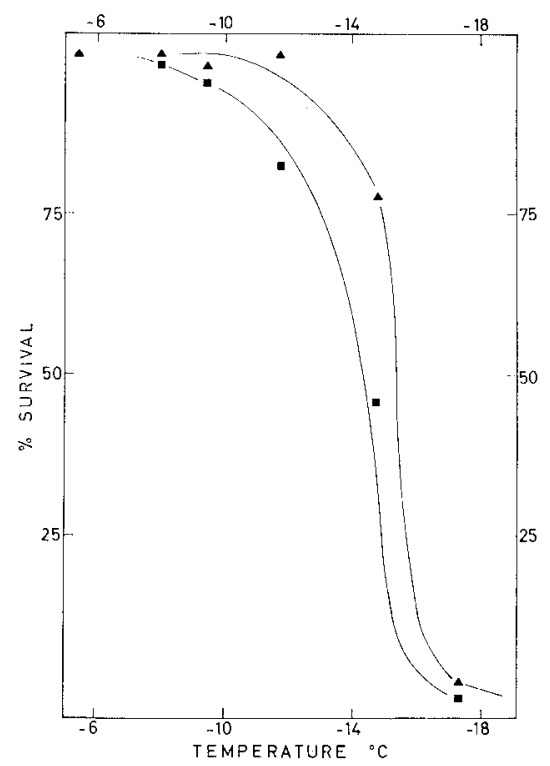

Fig. 6: The effect of fertilisation on the cold tolerance of the adult barnacle. A Animals bearing fertilized egg masses, $\mathbf{\square}$ animals without egg masses

high water animals and those collected from lower down the shore $(P=0.01)$, amounting on December 1965 to some 2 to 3 degrees C, the closely parallel curves for barnacles with and without egg masses show that all individuals had acquired appreciable tolerance, those with fertilised egg masses being only slightly, but significantly, more advanced $(\mathrm{P}=0.01)$ by about 1 degree $\mathrm{C}$. Hence the acquisition of cold tolerance appears not to be directly linked with the initiation of the breeding cycle. No difference was detected between the tolerance levels of first year and older animals.

The possible relationship between the decline in cold tolerance and the liberation of nauplii was investigated by modifying the nutrition of the parent and the time of hatching of the nauplii. Three groups of barnacles with advanced egg masses were held at ambient temperature in the laboratory from February 1966; one group were fed daily with Artemia salina larvae to induce hatching, a second group were immersed in a solution of hatching substance for half an hour to cause rapid premature hatching, and a third group were starved to prevent hatching (CRISP 1956). On March 2, 1966 and at intervals thereafter cold tolerance was measured (Table 2). 
The low lethal tolerance experiments, perhaps because the result in tissue damage to the parent and consequent liberation of hatching factor, are often followed by a mass liberation of nauplii, making it impossible to be certain whether a given individual had liberated its brood before the start of the experiment. However, Table 2, based on the best assessment possible, indicates that animals in which hatching had occurred were, if anything, more tolerant than those which still retained unhatched

Table 2

Effect of experimentally induced hatching and laboratory conditions on cold resistance. The estimated $50 \%$ lethal limit after 18 hours exposure is shown in body of table

\begin{tabular}{|c|c|c|c|c|c|}
\hline \multirow[b]{2}{*}{$\begin{array}{l}\text { Date of cold } \\
\text { tolerance test }\end{array}$} & \multirow[b]{2}{*}{$\begin{array}{c}\text { Reproductive } \\
\text { stage }\end{array}$} & \multicolumn{4}{|c|}{ Treatment } \\
\hline & & $\begin{array}{c}\text { Fed on } \\
\text { Artemia } \\
\text { nauplii from } \\
\text { 17. Febr. } 66 \\
\text { o C }\end{array}$ & $\begin{array}{c}\text { Starved in } \\
\text { laboratory } \\
\text { sea water } \\
\text { from } \\
\text { 17. Febr. } 66 \\
{ }^{0} \mathrm{C}\end{array}$ & $\begin{array}{c}\text { Hatching } \\
\text { factor applied } \\
\text { for half an } \\
\text { hour on } \\
\text { 17. Febr. } 66 \\
\text { o C }\end{array}$ & $\begin{array}{l}\text { Left on the } \\
\text { shore } \\
{ }^{\circ} \mathrm{C}\end{array}$ \\
\hline \multirow[t]{3}{*}{ 2. March 66} & $\begin{array}{l}\text { Barnacles with } \\
\text { egg masses }\end{array}$ & -16.7 & -16.3 & -16.4 & -15.6 \\
\hline & $\begin{array}{l}\text { Barnacles without } \\
\text { egg masses }\end{array}$ & -18.3 & -17.5 & -17.4 & -17.9 \\
\hline & Mean of sample & -17.5 & -17.0 & -17.2 & -16.4 \\
\hline \multirow[t]{3}{*}{ 31. March 66} & $\begin{array}{l}\text { Barnacles with } \\
\text { egg masses }\end{array}$ & -17.5 & -15.7 & - & - \\
\hline & $\begin{array}{l}\text { Barnacles without } \\
\text { egg masses }\end{array}$ & -17.7 & -16.8 & -16.8 & -9.8 \\
\hline & Mean of sample & -17.6 & -16.5 & -16.8 & -9.8 \\
\hline
\end{tabular}

eggs. This is the reverse of what would be expected if liberation was responsible for the observed loss of cold tolerance. But the mean values of M.L.T. did not differ appreciably with the various treatments, with the exception of those for the field animals which alone showed a definite loss of tolerance. The difference between field and laboratory animals was enhanced in later tests as shown by the table, and eventually on June 3, 1966 the starved group had retained a M.L.T. of $-18^{\circ} \mathrm{C}$ while the M.L.T. of field animals had dropped to $-6^{\circ} \mathrm{C}$. Hatching has therefore no influence on cold resistance; environmental factors in the field differ in some essential features from those in the laboratory and must be responsible for the changes observed.

\section{INFLUENCE OF DAY LENGTH ON COLD TOLERANCE}

An obvious environmental difference between the laboratory and field animals was daylight and day length. Half the remaining animals which had been fed or treated with hatching substance were therefore exposed from May 25, 1966 to June 13, 
1966 to a regime of $16 \mathrm{hrs}$ light at $70 \mathrm{ft}$ candles and $8 \mathrm{hrs}$ dark. The other half were placed in complete darkness for the same period. Field animals were collected and treated in the same way, all groups being maintained at the same temperature of $15.5^{\circ} \pm 0.5^{\circ} \mathrm{C}$. No change in cold resistance was observable after 19 days treatment among any of the groups.

\section{ACCLIMATION EXPERIMEN'TS}

Though little seasonal variation in the upper median lethal temperature was observed in animals collected from the shore, small changes were noted when animals were acclimated in the laboratory to temperatures above and below ambient.

Winter animals kept at $15^{\circ}$ to $17^{\circ} \mathrm{C}$ and at $3^{\circ}$ to $4^{\circ} \mathrm{C}$ for 2 weeks showed a very small rise and fall respectively of 0.25 degrees $\mathrm{C}$ in the upper limit (Table 3 ) but longer

Table 3

Effect of acclimation on lethal temperature. All specimens were collected from high water mark

\begin{tabular}{|c|c|c|c|}
\hline Experiment & Treatment & Period & $\begin{array}{c}\text { Median lethal } \\
\text { temperature }\end{array}$ \\
\hline \multirow[t]{2}{*}{1} & $\begin{array}{l}\text { Maintained at } 3^{0}-4^{0} \mathrm{C} \\
\text { Maintained at } 15^{0}-17^{0} \mathrm{C}\end{array}$ & $\begin{array}{l}\text { 6. Jan.-21. Jan. } 66 \\
\text { 6. Jan.-21. Jan. } 66\end{array}$ & $\begin{array}{l}\text { (Upper) } \\
43.5^{0} \mathrm{C} \\
44.0^{\circ} \mathrm{C}\end{array}$ \\
\hline & Collected from field & 21. Jan. 66 & $43.75^{\circ} \mathrm{C}$ \\
\hline \multirow[t]{2}{*}{2} & Maintained at $3^{0}-4^{0} \mathrm{C}$ & 15. Febr.-6. July 64 & $42.7^{0} \mathrm{C}$ \\
\hline & Collected from field & 6. July 64 & $43.75^{\circ} \mathrm{C}$ \\
\hline \multirow[t]{2}{*}{3} & $\begin{array}{l}\text { Maintained at } 15^{0}-17^{0} \mathrm{C} \\
\text { Maintained at } 3^{0}-4^{0} \mathrm{C}\end{array}$ & $\begin{array}{l}\text { 7. July-19. Dec. } 64 \\
\text { 7. July-19. Dec. } 64\end{array}$ & $\begin{array}{l}\text { (Lower) } \\
-6.0^{\circ} \mathrm{C} \\
-7.6^{\circ} \mathrm{C}\end{array}$ \\
\hline & $\begin{array}{l}\text { Collected from field } \\
\text { Collected from field }\end{array}$ & $\begin{array}{l}\text { 12. June } 65 \\
\text { 2. Dec. } 65\end{array}$ & $\begin{array}{r}-6.0^{\circ} \mathrm{C} \\
-16.8^{\circ} \mathrm{C}\end{array}$ \\
\hline
\end{tabular}

acclimation at low temperature over 3 months, extending from spring to summer, caused a fall of 1 degree $C$ in comparison with field animals.

Summer animals kept at summer sea water temperatures $\left(15^{\circ}\right.$ to $\left.17^{\circ} \mathrm{C}\right)$ thoughout autumn and winter predictably failed to become fertilized (CRISP 1957, CRISP \& CLEGG 1960) and retained the same lower median lethal temperature of $-6^{\circ} \mathrm{C}$ at which they started in the summer. Animals kept at $3^{0}$ to $4^{\circ} \mathrm{C}$ over the same period bred normally but showed only a small fall in M.L.T. from $-6^{\circ}$ to $-7.6^{\circ} \mathrm{C}$. Animals exposed to a normal intertidal environment, however, became extremely resistant to cold with a M.L.T. of $-17^{\circ} \mathrm{C}$.

Thus cold acclimation alone cannot account for the development of cold resistance in winter, nor, as we surmised from earlier evidence, is the development of cold resistance an inevitable accompaniment of breeding. 


\section{SIGNIFICANCE OF CHANGES IN TEMPERATURE TOLERANCE}

As remarked by SOUTHWARD (1958), injurious temperature extremes are unlikely to be met beneath the sea in temperate latitudes; only when the animal is exposed to the air is it likely to experience lethal temperatures. He quotes an observation of measurement of $38^{\circ} \mathrm{C}$ for the interior of a barnacle exposed to the sun, at which temperature heat coma would ensue and $50 \%$ of the population of Balanus balanoides would die in 45 minutes. Thus mortality caused by high summer temperature may be a contributory factor in determining the southern boundary of the species, especially on the east coast of the United States (BARnes 1958), where the animal extends to lower latitudes and endures much hotter summers than in Europe. An important adaptation reduces the danger of insolation to a substantial proportion of the intertidal populations of this species; the tendency which we have been able to demonstrate in the laboratory for the cyprids to settle on the shaded sides of objects.

Similarly, though the species can never be exposed to winter temperatures near the lethal point when under water, it is likely to be injured when exposed to severe frosts on the shore, and may be permanently frozen in ice during the winter at its northern limits. The remarkable resistance to low temperature at this period of the year, not only in the adult, but also in the incubating eggs and nauplius stages, constitutes a beautiful adaptation of an arctic species exposed to severe conditions in the high intertidal zone. Unlike the figures quoted for the upper lethal temperature, which is merely an index of "instantaneous" tolerance, the lower limits were measured over an $18 \mathrm{hr}$ period and are therefore conservative estimates of what the animal could tolerate when situated on a normal shore and immersed twice daily in the sea. The seasonal change accounts in part for the anomaly between Southward's (1958) measurement of a M.L.T. of $-10^{\circ} \mathrm{C}$ and Petersen's (1962) observation that in the arctic winter the species survives long periods at much lower temperature.

Not surprisingly the planktonic stages were found to be less tolerant than the adult, particularly the cypris stage. This was the least tolerant to both high and low temperatures extremes. Significantly, as soon as metamorphosis was completed, tolerance both of high and low temperature rose suddenly. The difference in tolerance between the planktonic and adult stages appears small in relation to the much greater range of temperatures that the animal must endure when exposed to the sun and frost, but it must be remembered that the method of testing with a more rapid rise in temperature ( 1 degree per minute for larvae, 0.2 degrees per minute for adults) will probably have reduced the difference between the observed M.L.T.'s for adult and larva respectively. If exposed for long periods the larvae would have undoubtedly shown less extreme values for M.L.T.; nevertheless, it is unlikely that temperatures that are directly lethal to them are ever encountered in the sea. There is some evidence that the larval stages can show some adaptation to very slow changes in temperature. We noted that cyprids held for a few days at $3^{0}$ to $4^{0} \mathrm{C}$ were markedly more cold resistant than those collected from the sea.

Both upper and lower limits as measured by our methods lie outside the range of the animal's normal activity. The upper median lethal point is some 12 degrees higher than the temperature at which the animal ceases to exhibit cirral activity. 
Though the upper lethal temperature varies little with the season or as a result of acclimation, the point of cessation of activity varies much more widely, namely from $28^{\circ} \mathrm{C}$ in winter to $32^{\circ} \mathrm{C}$ in summer, and similar changes are produced by high and low temperature acclimation. The lower point of activity of the species is very indefinite, the cirri beating ever more slowly down to sub-zero temperatures at whatever time of the year the barnacle is tested. However, at such low temperatures cirral movement is extremely slow and capture of active prey would be difficult.

It is not clear why the useful attribute of cold resistance should be lost in the cypris stage and in the adult between spring and autumn. Possibly the acquisition of cold resistance militates against some essential physiological or growth process. Rapidly differentiating tissues may be susceptible to damage and might be injured by the mechanisms which could protect relatively inactive tissues from the effects of severe cold. It may therefore be significant that cold resistance in the adult is accompanied by a form of physiological hibernation in which a number of organs are reduced or lost, and the animal's activity is depressed. The vesiculae seminales and the penis degenerate (MOORE 1935, CRISP \& PATEL 1960), and actively metabolising tissues, including the gonads and certain glands, enter a period of recession (CRISP 1954, Walley 1967). During this period the animal also ceases to moult (CRISP \& Patel 1960, BARNES 1962), the gut lining becomes apparently less active and feeding activity is greatly reduced (BARNES 1959) even if ample food is provided (RITZ \& CRISP in preparation). Its oxygen uptake is diminished and levels of R.N.A. fall to a minimum (BARNES, BARNES \& Finlayson 1963).

The late stage eggs, which also are highly resistant, are likewise not in active development, but contain well developed embryos in a state resembling diapause (CRISP \& SPENCER 1958). In contrast, the most susceptible part of the animal's life, the cyprid, represents a stage at which the tissues are poised for a drastic re-organization and in which new structures are about to be initiated at metamorphosis. The adult too is most susceptible to low temperature in June when new growth is taking place and the ovaries and testes are developing rapidly.

\section{MECHANISM OF RESISTANCE TO COLD}

Cold death has been attributed to various forms of injury and disorder (LUYET \& GeHeNio 1940, BĚLEHRÁdeK 1935, 1957). An early view was that damage was primarily due to ice crystal formation, and that therefore cold hardy forms could be protected by increasing their osmotic pressure, by supercooling, or by the solidification of the water at low temperature in an amorphous state (vitrification). In addition to the purely mechanical effect of ice crystals in distorting and tearing cells, the withdrawal of water may raise the internal osmotic pressure to a point at which cell constituents are disorganised (BACHMETJEw 1899, SALT 1950), and bubbles formed from dissolved gas no longer soluble in the ice and concentrated cell fluid can burst and destroy cells and tissues (Scholander et al. 1953). But in certain cold hardy animals at least, ice is now known to form (Scholander et al. 1953, Kanwisher 
1955). A substantial fraction of the body water can be frozen without causing death; the percentage of ice in a chironomid larva has been found to be as high as $90 \%$.

Until recently it was thought that ice crystals must be confined to the intercellular fluids if cell damage was to be avoided (Chambers \& Hale 1932, Asahina et al. 1954, Doebbler \& Cowley 1964), but a comparison of intra and extracellular freezing in the wheat stem sawfly led SALT (1961) to conclude that neither the site of ice formation nor the crystal size and configuration was critical to the extent of injury and the ability to recover.

Very significant to the acquisition of cold hardiness is the presence in the tissues of glycerol and polyunsaturated lipids. Glycerol has the function of lowering the freezing point, promoting supercooling, and giving protection when freezing occurs. It is present in the tissues of certain cold hardy animals (SALT 1959) and has been used to reduce mortality in plant tissue (ILJIN 1935), in mammalian spermatozoa (Polge 1957) and the related propylene glycol has been used to protect warm blooded animals subjected to freezing (SMITH 1956). A high degree of polyunsaturation in fats may also be advantageous in resistance to cold (ALLEN 1960).

In Balanus balanoides the oocytes during development become richly endowed with fat which has a high degree of unsaturation (DAwsON \& BARNEs 1966). This fat becomes available to the embryos after they have been shed into the mantle space during autumn, and may confer some advantage at the low temperatures at which they often develop during the winter. Such an advantage would not accrue to the adult, since the body of the barnacle (excluding the ovary and shell) does not contain large quantities of unsaturated fat in early spring nor presumably in winter (DAwson \& BARNes 1966). In fact, between October and late November, coinciding with the increased tolerance to cold, there is a sudden fall in body lipids (BARnes, Barnes \& FinLAyson 1963). Some of this loss may result from the emission of semen during copulation, but perhaps some represents a source of glycerol which would offer an alternative means of protecting the tissues from cold. Glycerol can also be synthesised from glycogen, but the levels of this metabolite fall only gradually throughout the summer and autumn. We propose to investigate the possible presence of glycerol and related substances promoting cold hardiness in this species in the near future.

\section{SUMMARY}

1. The barnacle Balanus balanoides exhibits little seasonal variation in upper lethal temperatures in North Wales.

2. There are marked seasonal changes in resistance to sub-zero temperatures, the lower lethal varying from $-6.0^{\circ} \mathrm{C}$ in June to $-17.6^{\circ} \mathrm{C}$ in January.

3. Exceptional tolerance to cold is acquired between December and January and is lost between February and April. Although these dates coincide with oviposition and naupliar liberation respectively, it was found that cold tolerance did not necessarily depend upon, or accompany, the normal breeding cycle.

4. Cold tolerance was not acquired by animals kept cold in the laboratory during winter, nor was it lost in animals kept in the laboratory during spring. There was 
no evidence that changes in nutrition or in the light régime led to loss of cold tolerance.

5. The cyprids were considerably less resistant to both high and low temperatures than the overwintering adults and the late-stage embryos. There was a marked increase in resistance at metamorphosis.

6. The appearance of cold tolerance in the adult coincides with a period of "physiological hibernation", involving loss of certain tissues, diminished feeding activity, respiration and biosynthesis. The metabolic inactivity of the animal may be a factor promoting the greatly increased tolerance to cold that we have observed, while the composition of the body fluids may also be modified during the winter in such a way as to protect the tissues.

\section{ACKNOWLEDGEMENTS}

We wish to thank the Department of Scientific and Industrial Research (now the Natural Environment Research Council) for a grant to cover the cost of equipment. We are most indebted to the staff of the Workshop for assisting in the development of the apparatus.

\section{LITERATURE CITED}

Allen, M. B., 1960. Utilisation of thermal energy by living organisms. In: Comparative biochemistry. Ed. by M. Florkin \& H. S. Mason. Academic pr., New York, 1, 487-514.

AndRews, F. B., 1925. The resistance of marine animals of different ages. Publs Puget Sound mar. biol. Sin 3, 361-363.

Asahina, E., Aoki, K. \& Shinozakr, J., 1954. The freezing process of frost-hardy caterpillars. Bull. ent. Res. 45, 329-339.

Bachmetjew, P., 1899. Über die Temperatur der Insecten nach Beobachtungen in Bulgarien. Z. wiss. Zool. 66, 521-604.

Barnes, H., 1958. Regarding the southern limits of Balanus balanoides (L.). Oikos 9, 139-157.

- 1959. Temperature and the life-cycle of Balanus balanoides. In: Marine boring and fouling organisms. Ed. by D. L. Ray. Univ. of Washington pr., Seattle, 234-245.

- 1962. The so-called anecdysis in Balanus balanoides and the effect of breeding upon the growth of the calcareous shell of some common barnacles. Limnol. Oceanogr. 7, 462-473.

- Barnes, M. \& Finlayson, D. M., 1963. Seasonal changes in body weight, biochemical composition and oxygen uptake in two common boreo-arctic cirripedes Balanus balanoides and B. balanus. J. mar. biol. Ass. U. K. 43, 185-211.

BËLEYRÁdEK, J., 1935. Temperature and living matter. Protoplasma-Monogr. 8, 1-277.

- 1957. Physiological aspects of heat and cold. A. Rev. Physiol. 19, 59-82.

Bodenheimer, F. S. \& Klein, H. Z., 1930. Uber die Temperaturabhängigkeiten von Insekten. 2. Die Abhängigkeit der Aktivität bei der Ernteameise, Messor semirufus, E. ANDRÉ, von Temperatur und anderen Faktoren. Z. vergl. Physiol. 11, 345-385.

BovbJeRG, R. V., 1952. Comparative physiology and ecology of the crayfish Orconectes propinquus and Cambarus fodiens. Pbysiol. Zool. 25, 34-55.

Bovee, E. C., 1949. Studies on the thermal death of Hyalella azteca Saussare. Biol. Bull. mar. biol. Lab., Woods Hole 96, 123-128.

Chambers, R. \& Hale, H. P., 1932. The formation of ice in protoplasm. Proc. R. Soc. Lond. (B) 110, 336-352.

CRISP, D. J., 1954. The breeding of Balanus porcatus (DA CosTA) in the Irish Sea. J. mar. biol. Ass. U. K. 33, 473-496. 
- 1955. The rate of development of Balanus balanoides (L.) embryos in vitro. J. Anim. Ecol. 28, 119-132.

- 1956. A substance promoting hatching and liberation of young in cirripedes. Nature, Lond. 178, 263.

- 1957. Effect of low temperature on the breeding of marine animals. Nature, Lond. 179, 1138-1139.

- (Ed.) 1963. The effects of the severe winter of 1962-63 on marine life in Britain. J. Anim. Ecol. 33, 165-210.

- \& ClegG, D. J., 1960. The induction of the breeding condition in Balanus balanoides (L.). Oikos 11, 265-275.

- \& Patel, B. S., 1960. The moulting cycle in Balanus balanoides (L.). Biol. Bull. mar. biol. Lab., Woods Hole 118, 31-47.

- \& Spencer, C. P., 1958. The control of the hatching process in barnacles. Proc. R. Soc. Lond. (B) 148, 275-299.

Dawson, R. M.C. \& Barnes, H., 1966. Studies in the biochemistry of cirripede eggs. 2. Changes in lipid composition during development of Balanus balanoides and B. balanus. J. mar. biol. Ass. U. K. 46, 249-261.

Dickie, L. M., 1958. Effects of high temperature on survival of the giant scallop. J. Fish. Res. Bd Can. 15, 1189-1211.

- \& Medcof, J. C., 1963. Causes of mass mortalities of scallops (Placopecten magellanicus) in the South-western Gulf of St. Lawrence. J. Fish. Res. Bd Can. 20, 451-482.

Doebbler, G. F. \& Cowley, C. W., 1964. Cryobiology. Int. Sci. Technol. No 30 (June), 58-71.

DOUdoRofF, P., 1942. The resistance and acclimatisation of marine fishes to temperature changes. 1. Experiments with Girella nigricans (Ayres). Biol. Bull. mar. biol. Lab., Woods Hole 83, 219-244.

EDWARDS, G. A. \& IRVING, L., 1943. The influence of temperature and season upon the oxygen consumption of the sand crab Emerita talpoida SAY. J. cell. comp. Physiol. 21, 169-182.

Evans, R. G., 1948. The lethal temperatures of some common British littoral molluscs. J. Anim. Ecol. 17, 165-173.

FRY, F. E. J., 1947. Effects of the environment on animal activity. Univ. Toronto Stud. (Biol. Ser.) $=$ (Publs Ont. Fish. Res. Lab. 68) 55, 1-62.

- 1957. The lethal temperature as a tool in taxonomy. Année biol. 33, 205-219.

Gunter, G., 1957. Temperature. In: Treatise on marine ecology and paleoecology. Vol. 1: Ecology. Ed. by J. W. Hedgpeth. Mem. Geol. Soc. Am. 67, 159-184.

Hathaway, E. S., 1927. Quantitative studies of the changes produced by acclimatisation in the tolerance of high temperatures by fishes and amphibians. Bull. Bur. Fish., Wash. 43, 169-192.

HofF, J. G. \& WESTMAN, J. R., 1966. The temperature tolerance of three species of marine fishes. J. mar. Res. 24, 131-140.

Huntsman, A. G. \& Sparks, M. I., 1924. Limiting factors for marine animals. 3. Relative resistance to high temperatures. Contr. Can. Biol. Fish. (N. S.) 2, 97-114.

ILJIN, W. S., 1935. The relation of cell sap concentration to cold resistance in plants. Zap. naučno-issled. Ob’ed. russk. svob. Univ. Prage (Bull. Ass. russ. Rech. scient. Prague) 3 (8) No. 13, 33-55.

KANWISHER, J. W., 1955. Freezing in intertidal animals. Biol. Bull. mar. biol. Lab., Woods Hole 109, 56-63.

KINNE, O., 1963. The effects of temperature and salinity on marine and brackish water animals. 1. Temperature. Oceanogr. mar. Biol. A. Rev. 1, 301-340.

KROG, J,, 1954. The influence of seasonal environmental changes upon the metabolism, lethal temperature and rate of heart beat of Gammarus limnaeus SMITH taken from an Alaskan lake. Biol. Bull. mar. biol. Lab., Woods Hole 107, 397-410.

Luyet, B. J. \& Gehenio, P., 1940. The mechanism of injury and death by low temperature. A review. Biodynamica 3, 33-99.

MCleEse, D. W., 1956. Effects of temperature, salinity and oxygen on the survival of the American lobster. J. Fish. Res. Bd Can. 13, 247-272. 
Marlier, G., 1949. Relation entre température léthale et habitat normal chez les larves de trichoptères. C. r. Séanc. Soc. Biol. 143, 100-101.

Marshall, S. M., Nicholls, A. G. \& OrR, A. P., 1935. On the biology of Calanus finmarchicus. 6. Oxygen consumption in relation to environmental conditions. 7 . mar. biol. Ass. U. K. 20, 1-27.

Moore, H. B., 1935. The biology of Balanus balanoides. 3. The soft parts. J. mar. biol. Ass. U. K. 20, 263-274.

OrR, P. R., 1955. Heat death of whole animals and tissues. Physiol. Zool. 28, 290-302.

Petersen, G. H., 1962. The distribution of Balanus balanoides (L.) and Littorina saxatilis (OLvvi) var. groenlandica MENKE in northern west Greenland. Meddr Gronland 159 (No 9), 1-47.

Polge, C., 1957. Low temperature storage of mammalian spermatozoa. Proc. R. Soc. Lond. (B) 147, 498-508.

Precht, H., 1964. Uber die Resistenzadaptation wechselwarmer Tiere an extreme Temperaturen und ihre Ursachen. Helgoländer wiss. Meerestnters. 9, 392-411.

SALT, R. W, 1950. Time as a factor in the freezing of undercooled insects. Can. J. Res. (D) 28, 285-291.

- 1959. Role of glycerol in the cold-hardening of Bracon cephi (GaHan). Can. J. Zool. 37, 59-69.

- 1961. A comparison of injury and survival of larvae of Cephus cinctus NorT after intracellular and extracellular freezing. Can. J. Zool, 39, 349-357.

Scholander, P. F., Flagg, W., Hock, R. J. \& Irving, L., 1953. Studies on the physiology of frozen plants and animals in the arctic. J. cell. comp. Physiol. 42 (Suppl. 1), 1-56.

SMITH, A. U., 1956. Studies on golden hamsters during cooling to and rewarming from body temperatures below $0^{\circ} \mathrm{C}$. 1 . Observations during chilling, freezing and supercooling, Proc. R. Soc. Lond. (B) 145, 391-407.

Southward, A. J., 1958. Note on the temperature tolerance of some intertidal animals in relation to environmental temperatures and geographical distribution. J. mar. biol. Ass. U.K. 37, 49-66.

Sprague, J. B., 1963. Resistance of four freshwater crustaceans to lethal high temperature and low oxygen. J. Fish. Res. Bd Can. 20, 387-415.

Todn, M. E. \& Dennel, P. A., 1960. The influence of temperature and salinity on heat tolerance in two grapsoid crabs, Hemigrapsus nudus and Hemigrapsus oregonensis. Biol. Bull, mar. biol. Lab., Woods Hole 118, 150-172.

Vernon, H. M., 1899. The death temperature of certain marine organisms. J. Physiol. 25, $131-136$.

WALLEY, L. J., 1967. The cirral glands: a new type of epidermal gland in cirripedes. Crustaceana 12, 151-158.

\section{Discussion following the paper by CRISP \& RITZ}

WEBB: Why do not barnacles survive even lower water temperatures once they have achieved a mechanism that permits them to live below the freezing point of sea water?

CRIsp: Evidently a cold hardy animal can tolerate the freezing of a high proportion of the tissue fluid but not complete freezing. For instance, KANWISHER found about $70 \%$ of water frozen in Mytilus edulis, and Scholander found nearly $90 \%$ frozen in arctic chironomids. However, if the animal can survive complete desiccation, it can also survive very much lower temperatures than $-20^{\circ} \mathrm{C}$.

WEBB: Were your results confirmed by the survival of barnacles during the cold winter of 1962-63?

Crisp: Yes, from the observations during 1962-63 Balanus balanoides was one of the most hardy intertidal species. 
BARNES: How do you imagine that glycerol is produced at a time when the metabolic activity is at its lowest? With regard to extreme low temperatures in the Arctic, it should be remembered that the animals are insulated by the high specific heat of ice.

CRISP: We have not, of course, yet demonstrated that glycerol is formed. If it were, then presumably it would form during the period when cold tolerance rises most rapidly, that is, during November. At this time air and sea temperature would not be so low as to inhibit metabolic activity completely.

Thorson: According to a new Danish paper (Höpner Petersen 1966) Balanus balanoides in Greenland seem to have survived winter temperatures lower (perhaps $-20^{\circ} \mathrm{C}$ or more) than have those given by Dr. Crisp. Does the lecturer regard these Greenland specimens as belonging to another physiological race?

CRIsP: Until we have made comparisons in the laboratory, we cannot be sure that the Greenland specimens have a greater tolerance than European specimens though the evidence does suggest that this is so. From other evidence, such as the larger size of the planktonic nauplius stages and from geographic proximity, one would expect the Greenland specimens to belong to a physiological race which resembled that on the East Coast of America rather than that occurring in Europe. 